W zakończeniu polskiemu historykowi wypadnie dodać, iż wygasająca od wielu lat dyskusja w naszej rodzimej historiografii nad kronikami Odrodzenia w Polsce i Rzeczypospolitej, dzięki rosyjskiemu historykowi przywołana została ponownie.

Teresa Chynczewska-Hennel Wydział Historyczno-Socjologiczny Uniwersytet w Białymstoku

\title{
Marcin Borys, Polska emigracja do Stanów Zjednoczonych do 1914 roku, Toruń 2011, ss. 224
}

Z zainteresowaniem sięgnąłem po pracę zapowiadającą - jak wskazuje tytuł - problematykę polskiej emigracji do Stanów Zjednoczonych. Autor zajmuje się historią polskiej emigracji, dziejów Polonii amerykańskiej, historią społeczną XIX w.

Ramy czasowe niniejszej pracy obejmują praktycznie kilka wieków, począwszy od 1608 roku, a więc pojawienia się pierwszych polskich osadników w Ameryce Północnej, do 1914 roku i wybuchu I wojny światowej.

Książka składa się ze wstępu, trzech rozdziałów i zakończenia. Tekst zawiera również 7 tabel. Załączona bibliografia składa się ze źródeł drukowanych (wydawnictwa źródłowe, prasa, kalendarze, pamiętniki, wspomnienia, korespondencja, księgi jubileuszowe) oraz opracowań (132 pozycji).

Praca nosi z założenia charakter syntetyczny, a materiały źródłowe (w tym XIX-wieczna prasa polonijna z USA) zostały wykorzystane przez Autora raczej dla urozmaicenia narracji. Bazę źródłową można określić jako dość skąpą, Autor nie wykorzystał bowiem żadnych źródeł archiwalnych. Wydawnictwa źródłowe obejmują dane statystyczne dotyczące polskiej ludności Chicago, teksty źródłowe związane z historią Indian, Konstytucję USA oraz kilka innych pozycji. Autor wybiórczo sięgnął do prasy („Dziennik Chicagowski” z lat 1893-94, 1897-98, „Naród Polski” z roku 1897), wykorzystując jako źródła również współczesne magazyny polonijne: „Kalejdoskop” (Weekendowy Magazyn „Dziennika Związkowego”) z 2006 r. oraz „Polonię” z 2007 r. Zarówno XIX- jak i XXI-wieczne periodyki reprezentują - $\mathrm{i}$ to bardzo selektywnie - wyłącznie prasę polonijną z Chicago. Autor pominął m.in. tak cenne źródła, jak pamiętniki emigrantów ze Stanów Zjednoczonych przygotowane na konkurs Instytutu Gospodarstwa Społecznego w latach 1930., a opublikowane potem w dwutomowej edycji ${ }^{1}$.

1 Pamiętniki emigrantów: Stany Zjednoczone, red. J. Dziembowska, Warszawa 1977, t. I-II. 
Wykaz literatury przedmiotu jest daleko niekompletny i nie uwzględnia np. działalności wydawniczej i naukowej Instytutu Amerykanistyki i Studiów Polonijnych Uniwersytetu Jagiellońskiego, specjalizujących się w tej tematyce. W ostatnich latach ukazały się kolejne ciekawe prace dotyczące omawianego tematu. We współredagowanym przez pracowników naukowych Instytutu kwartalniku „Studia Migracyjne - Przegląd Polonijny” (przed 2009 - „Przegląd Polonijny”) opublikowano analizę porównawczą dotyczącą metodologii badań nad imigracją/etnicznością w Europie i USA, autorstwa Ewy Morawskiej² oraz pracę Jose Moya dotyczącą ogólnych zagadnień imigracji i asymilacji w USA od połowy XIX w. do 1930 r. $^{3}$ Natomiast w zeszytach naukowych Instytutu „Ad Americam. Journal of American Studies", promujących studia i badania amerykanistyczne $\mathrm{w}$ Polsce $\mathrm{w}$ tym za pośrednictwem prac o charakterze interdyscyplinarnym, w 2002 r. opublikowano interesujące studium porównawcze Tadeusza Palecznego, dotyczące emigracji do Stanów Zjednoczonych Polaków i Irlandczyków4.

Warto też wspomnieć o opracowaniach badaczy Środkowoeuropejskiego Forum Badań Migracyjnych i Ludnościowych w Warszawie. Z najnowszych tytułów dotyczących badanej problematyki warto wskazać ciekawą i wartościową pracę porównawczą Briana McCooka, poświęconą emigrantom polskim w regionach górniczych - Zagłębiu Ruhry oraz Północno-Wschodniej Pensylwanii ${ }^{5}$ Ze względu na rok wydania (2011), być może pozycja ta nie jest znana Autorowi.

W pierwszym rozdziale zatytułowanym Polska emigracja polityczna $i$ zarobkowa do końca XIX wieku Autor pobieżnie omawia emigrację z ziem polskich w dłuższym przedziale czasowym. W tej części pracy nie koncentruje uwagi wyłącznie na emigracji do USA, bowiem jej znaczne fragmenty dotyczą emigracji polskiej do innych krajów - zarówno pozaeuropejskich (Kanada, Brazylia, Argentyna), jak i europejskich. Przedstawiona natomiast historia emigracji z ziem polskich do Ameryki Północnej obejmuje wydarzenia, poczynając od XVII-wiecznych: kolonizacji Nowego Świata z udziałem nielicznych Polaków oraz wychodźstwa przedstawicieli niektórych grup religijnych z I Rzeczypospolitej w drugiej połowie stulecia. Wspomniane są też początki emigracji politycznej w XVIII wieku, która nabiera większej skali

2 E. Morawska, Badania nad Imigracją/Etnicznościa w Europie i Stanach Zjednoczonych: Analiza porównawcza, „Studia Migracyjne - Przegląd Polonijny” (1) 2009, s. 7-26.

3 J. Moya, Immigration, Development, and Assimilation in the United States in a Global Perspective, 1850-1930, „Studia Migracyjne - Przegląd Polonijny” (3) 2009, s. 89-104.

4 T. Paleczny, A Comparative Study of Emigration to the United States from Ireland and Poland, „Ad Americam” (3) 2002.

5 B. McCook, The Borders of Integration. Polish Migrants in Germany and the United States, 1870-1924, Athens (Ohio) 2011. 
w okresie porozbiorowym, zwłaszcza po upadkach powstań listopadowego i styczniowego. Układając swoja narrację w porządku chronologicznym, Autor wzmiankuje dalej o emigracji zarobkowej w drugiej połowie XIX i początku XX wieku. Jak pisze (s. 9): „Sytuacja zmieniła się dopiero w drugiej połowie XIX w., kiedy czynniki natury politycznej zaczęły ustępować motywom o podłożu ekonomicznym".

W tym miejscu brakuje choćby krótkiej wzmianki, że migracja z Polski do Stanów Zjednoczonych była i jest częścią procesów ogólnoeuropejskich i ogólnoświatowych. Sytuacja w Europie w XIX w. diametralnie się zmieniła wraz z postępem cywilizacyjnym, rozwojem gospodarki kapitalistycznej, przemysłu, transportu i wdrożeniem na niespotykaną dotychczas skalę w historii ludzkości wynalazków technicznych. W okresie od połowy XVIII wieku do 1900 roku liczba ludności w Europie wzrosła trzykrotnie, z 140 do 430 mln osób (od 17\% do $25 \%$ ludności świata), ponieważ śmiertelność zmniejszyła się ze względu na poprawę warunków życiowych, a płodność została jeszcze na wysokim poziomie. Produkcja masowa we wszystkich gałęziach gospodarki oraz rozwój środków transportu stworzyły podstawy do największej migracji w historii świata, która nie byłaby możliwa bez kolei żelaznych i parowców. Znaczne obniżenie kosztów przetransportowania ludzi i ładunków w wyniku wojny cenowej między przewoźnikami transatlantyckimi, przyczyniło się do powstania współczesnego handlu światowego. Ten z kolei spowodował znaczną aktywizację przemieszczania się ludzi do pracy między krajami. Oba wspomniane zjawiska dały o sobie znać ze zdwojoną siłą jeszcze przed wybuchem I wojny światowej w 1914 roku$^{6}$.

Można zgodzić się z Autorem odnośnie zaproponowanej przez niego górnej granicy czasowej rozpatrywanego okresu, kiedy pisze on, że „Wybuch wojny w Europie niemal całkowicie wstrzymał napływ nowych emigrantów" (s. 8). Wątpliwości budzi natomiast przypisywanie zbyt idealistycznych pobudek, które jakoby decydowały o zaniechaniu masowych wyjazdów za granicę w celach zarobkowych. Przed Polakami stanęła zaś wizja odzyskania niepodległego państwa. W tym momencie na bok należato odłożyć wszelkie myśli o wyjeździe za granicę. Cały wysitek koncentrowano na odbudowie kraju (s. 8). Wizja i nadzieje na odzyskanie własnego państwa stała się oczywista dla szerokich kręgów ludności polskiej na emigracji i w kraju dopiero pod koniec wojny, a prawdziwa odbudowa ojczyzny rozpoczęła się jeszcze później - po wojnie polsko-bolszewickiej. Przecież emigracja z ziem polskich występowała również po odbudowie państwa polskiego, a mniejsza skala zjawiska w porównaniu z okresem przedwojennym była spowodowana głównie zmianą polityki imigracyjnej USA w tym okresie, a zwłaszcza wprowadzeniem Immigration Acts z 1921 i 1924 znacznie ograni-

6 J. Moya, op. cit., s. 91. 
czających imigrację z krajów Europy Środowo-Wschodniej i Południowej. Natomiast część osób zdecydowała się wrócić po wojnie ze Stanów Zjednoczonych do rodzinnych stron 7 .

$\mathrm{Na}$ więcej uwagi zasługują też, moim zdaniem, ogólne procesy urbanizacyjne. Ludność Europy od połowy XIX w. do I wojny światowej masowo migrowała do miejscowości i regionów bardziej uprzemysłowionych i zurbanizowanych w obrębie własnego kontynentu oraz przemieszczała się w tym celu przez Atlantyk. Do USA w tym okresie wyjechało kilka milionów Polaków, głównie chłopów. Kształtowanie się Polonii amerykańskiej w znacznym stopniu było procesem urbanizacyjnym, bowiem ludność pierwotnie wiejska - z racji zatrudnienia w przemyśle - w naturalny sposób zmieniała swoje przyzwyczajenia i styl życia.

Większość emigrantów polskich nie zamierzała na stałe zostawać za oceanem, dążąc wyłącznie do poprawy własnej sytuacji materialnej. Życie potoczyło się jednak inaczej, a mimo pochodzenia $\mathrm{z}$ trzech różnych zaborów, na nowej ziemi emigranci polscy stworzyli wspólnotę narodową. Potomkowie emigrantów zarobkowych z przełomu XIX i XX wieku stanowią dzisiaj podstawową część Polonii w USA.

W rozdziale drugim Autor podaje podstawowe informacje z historii Stanów Zjednoczonych od okresu kolonizacji do przełomu XIX i XX wieku. Przedstawia tu również problematykę imigracji do Stanów Zjednoczonych, dążąc do omówienia - zresztą pobieżnie - ruchów migracyjnych do tego kraju z Europy i innych części świata. Rozdział ten Autor zamyka wzmiankami dotyczącymi kształtowania się polityki antyimigracyjnej USA na przełomie XIX i XX wieku. Jeszcze we Wstępie do książki (s. 8) Autor zauważa, że szczególnie interesujące w kontekście dzisiejszych starań Polski o wprowadzenie ruchu bezwizowego wydaje się omówienie amerykańskiej polityki imigracyjnej'. Bez wątpienia jest to ważny wątek, ale bez uwzględnienia całej XX-wiecznej amerykańskiej polityki imigracyjnej nie da się wprost powiązać wydarzeń z przełomu XIX i XX wieków z tym, co mamy współcześnie.

W pierwszym podrozdziale Pierwsi Polacy na kontynencie amerykańskim, ostatniego trzeciego rozdziału Polacy w USA - ich historia, poczatki osadnictwa $i$ kształtowanie sie sieci parafialnej autor wspomina między innymi najwybitniejszych Polaków w Stanach Zjednoczonych, m.in. rodziny Zaborowskich i Sadowskich, Tadeusza Kościuszki, Kazimierza Pułaskiego, emigrantów po powstaniu listopadowym, uczestników wojny secesyjnej, emigrantów po powstaniu styczniowym.

7 A. Walaszek, Reemigracja ze Stanów Zjednoczonych do Polski po I wojnie światowej (1919-1924), Kraków 1983. 
Kolejny podrozdział Początki i rozwój osadnictwa dotyczy głównie wydarzeń z XIX wieku, obejmuje kwestie związane z podjęciem decyzji odnośnie wyjazdu przez przyszłych emigrantów, opisuje warunki podróży. Są tam przytoczone informacje dotyczące rozmiarów badanego zjawiska na podstawie danych dotyczących wychodźstwa z poszczególnych zaborów oraz dotyczące struktury społeczno-zawodowej emigrantów, polskich organizacji narodowych w USA, polskiej prasy w tym kraju. W tej części książki Autor odwołuje się m.in. do prac Andrzeja Brożka ${ }^{8}$ i Floriana Stasika ${ }^{9}$.

Pierwszymi organizacjami polonijnymi były te związane z Kościołem katolickim. Ostatni podrozdział rozdziału trzeciego dotyczy właśnie tworzenia polskiej sieci parafialnej w USA. Jest on, moim zdaniem, najbardziej wartościową - choć bynajmniej nie nowatorską - częścią całej książki. Brak natomiast odwołania się do książki Doroty Praszałowicz Amerykańska etniczna szkoła parafialna ${ }^{10}$, chociaż w Bibliografii Autor przytacza inne pozycje jej autorstwa. Do ciekawych wątków pracy można zaliczyć również opis konfliktu katolików polskich z miejscową hierarchią katolicką o pochodzeniu przeważnie irlandzkim i niemieckim, co przyczyniło się na początku XX w. do utworzenia Polskiego Narodowego Kościoła Katolickiego z inicjatywy ks. Franciszka Hodura (konsekrowanego później na biskupa). Tu Autor nie wykorzystał jednak cennych dzieł Tadeusza Majewskiego ${ }^{11}$ czy Czesława Kuliczkowskiego ${ }^{12}$.

$\mathrm{Na}$ więcej uwagi zasługuje natomiast sprawa integracji emigrantów do społeczeństwa amerykańskiego, zwłaszcza w zakresie przysługujących emigrantom z ziem polskich praw obywatelskich, politycznych i gospodarczych. Przydałaby się też analiza wpływu następujących czynników: poziomu organizacji przemysłu w USA, poziomu interwencji państwa w sprawy gospodarcze i kulturowe, stanu społeczeństwa obywatelskiego, na możliwość integracji Polaków etc. Istniał problem dzieci emigrantów polskich w szkołach w Stanach Zjednoczonych, które z reguły uznawano za mniej inteligentne od dzieci innych grup etnicznych ze względu na słabą znajomość języka angielskiego oraz mniejszy w porównaniu $\mathrm{z}$ innymi grupami imigrantów wysiłek rodziców polskich skierowany na wykształcenie dzieci ${ }^{13}$.

Ogólnie, analizując braki w tekście rozpatrywanej pracy, należy stwierdzić, że wynikają one po części z ogólnych założeń Autora, a także związane są $\mathrm{z}$ nieuwzględnionymi $\mathrm{w}$ ramach książki historią i metodologią badań

\footnotetext{
8 A. Brożek, Polonia amerykańska 1854-1939, Warszawa 1977.

9 F. Stasik, Polska emigracja w Stanach Zjednoczonych Ameryki 1865-1914, Warszawa 1985.

10 D. Praszałowicz, Amerykańska etniczna szkoła parafialna: studium porównawcze trzech wybranych odmian instytucji, Wrocław 1986.

11 T. Majewski, Biskup Franciszek Hodur i jego dzieło, Warszawa 1987.

12 Cz. Kuliczkowski, Father Franciszek Hodur, Scranton 2002.

13 B. McCook, op. cit., s. 29.
} 
przedmiotu. Problem złożonego zjawiska emigracji jest problemem interdyscyplinarnym, w badaniach nad nim, pomimo wątków historycznych, występują też wątki socjologiczne, politologiczne, demograficzne, antropologiczne, ekonomiczne, prawnicze oraz dotyczące geografii społecznej. Główne współczesne podejścia metodologiczne do emigracji można znaleźć we wspomnianej wyżej pracy Ewy Morawskiej ${ }^{14}$.

Ponieważ Autor zajmuje się popularyzacją historii, widocznie jego zamiarem było przygotowanie tekstu zrozumiałego dla różnych grup odbiorców oraz ogólne wprowadzenie czytelnika w ciekawy i być może nie do końca dobrze znany odbiorcy temat. Mając na uwadze rozległą literaturę przedmiotu, z której Autor skorzystał w niepełnym stopniu, treść książki może budzić pewien niedosyt, zwłaszcza w zakresie przebiegu procesów stopniowego przystosowania się emigrantów polskich do nowych warunków życia za Atlantykiem, kształtowania się świadomości narodowej tej grupy, jej stopniowego awansu ekonomicznego i włączania się w życie społeczno-polityczne USA.

Zrozumiała jest chęć przedstawienia przez Autora badanego zjawiska na szerszym tle procesów migracyjnych, wątpliwości może budzić natomiast obfitość stron, niedotyczących bezpośrednio omawianej tematyki.

Reasumując, tytuł książki niezupełnie odzwierciedla jej zawartość, w związku z czym pracy nie można uznać za udaną. Nawet pomijając sprawę niewykorzystanej bazy źródłowej do podjętego tematu, częściowe tylko uwzględnienie przez Autora dostępnej literatury przedmiotu, należy uznać, że rozpatrywane opracowanie niestety nie spełnia oczekiwań czytelników zainteresowanych problematyką polskiej emigracji do Stanów Zjednoczonych.

Vadzim Pauliuchuk

Wydział Historyczno-Socjologiczny Uniwersytet w Białymstoku

\section{Mykoła Riabczuk, Ponad resentymentami. Czytając Wasyla Kuczabskiego, „Arcana” nr 98-99 (2-3/2011, s. 245-254.}

W dwumiesięczniku „Arcana”, numery 98-99 (2-3/2011) ukazał się zgrabny artykuł Mykoły Riabczuka, dotyczący książki opublikowanej w 1934 roku w Berlinie przez Wasyla Kuczabskiego, a opracowanej przez niego w okresie, gdy przebywał w Niemczech jako ukraiński emigrant. Autor artykułu starał się wykazać, że książka przez niego omawiana, prezentuje się jako opracowanie rzeczowe i nacechowane obiektywizmem. Nie zaznaczył jednak, że w tej niemieckojęzycznej

14 E. Morawska, op. cit. 